\title{
Environmental Degradation and Landscape Management of the Nallamalai and Erramalai Hills of the Rayalaseema Region, Andhra Pradesh, India Using Geospatial Technology
}

\author{
Kommu Somanna', Mendu Sambasiva Rao ${ }^{2}$ \\ ${ }^{1,2}$ Dept. of Geography, Sri Krishnadevaraya University, Anantapuramu, Andhra Pradesh, India
}

\begin{abstract}
The Nallamalai and Erramalai hills of the Rayalaseema region posses rich biotic and mineral resources. They are formed of structural hills and cuesta hills enclosing the Kadapa and Kunderu valleys. They are also formed of Proterozoic formations consisting of shales, dolomite, limestone and quartzite. The Nallamalai hills raised to a height of about 600 to 900 meters above MSL and are covered with thick dry deciduous forests. The Erramalai hills range in height from 300 to 600 meters above MSL and are covered with scrubs and shrubs. The IRS IB Geo-coded data on scale 1:50,000 and Survey of India topographic sheets on scale 1:50,000 are used to map the ecologically disturbed zones in Nallamalai hills and land degradation due to over exploitation of mineral resources of the Erramalai hills. The intensity of soil removal, Sediment Yield Index and Erosion Index are worked out at sub-basin level and the environmental degraded zones are delineated. Based on the intensity of ecological and environmental degradation a few suggestions are made for better landscape management of the Erramalai and Nallamalai hills.
\end{abstract}

Keywords: Proterozoic, deciduous, ecologically, intensity, degraded.

\section{Introduction}

Land degradation is defined as the land is subjected to degradation processes by weathering and mass wasting naturally and degradation due to man"s interference artificially. Erosion is a major part of land degradation which involves detachment and transportation of soil. The natural erosion under balanced conditions of climate, land, water forests and vegetative cover are responsible for weathering and disintegration of rocks which decomposed organic matter which got deposited on the surface during the slow process of soil formation. The top soil is the basis of preservation and growth of life on earth. Encroachments for cultivation, tree felling for firewood, small timber, forest fires, uncontrolled grazing, construction of major dams across rivers, roads and railway lines, urbanization and industrialization created ecological disturbances and paved a way for heavy soil loss in the hilly terrain. It has been estimated in India that out of 329 million hectares of land available about 150 million hectares of land is subjected to water or wind erosion. It is about $53.3 \%$ of the geographical area of our country. The land is subjected to various erosion and land degradation problems like salinity, alkalinity, water logging, ravenous and gully erosion, shifting cultivation and desertification. It has also been estimated that sheet and rill erosion takes place at the rate of 4 to 10 tons/ha/year in red soils 17 to 43 tons/ha/ year in black soils and 4 to 14 tons/ha/ year in alluvial soils. Gully erosion has resulted soil loss of about 33 tons/ha/year and hillside erosion in landslide areas has resulted into soil loss of 80 tons/ha/year. In the recent years annual soil erosion rates in India was estimated by [1] as about 5.334 million tons or 16.35 tons/ha/year due to agriculture and associated activities.

\section{Study Area}

The Nallamalai, Erramalai, Palakonda, Velikonda, Tirumala and Seshachalam hills cover an area of about $51.142 \mathrm{~km}^{2}$. They are located in between $77^{\circ}$ to $80^{\circ} \mathrm{E}$. longitude and $13^{0} .30^{\text {ec }}$ to $16^{0} .20^{\text {ec }} \mathrm{N}$. latitude. The region enjoys dry sub humid climate and falls in the parts of Anantapuramu, Chittoor, Y.S.R.Kadapa, Guntur, Kurnool, Mahaboob Nagar, Nellore and Prakasham districts of Andhra Pradesh.

\section{Objectives}

The main objectives of the research paper are:

1) To describe the ecologically disturbed and degraded pockets

2) To evaluate the Environmental Impacts Assessment and

3) To suggest remedial measures for eco-development and Environmental management of the Nallamalai and Erramalai hilly region.

\section{Methodology}

The land resources of the Nallamalai and Erramalai hilly regions are evaluated based on studies from Survey of India topographic sheets on scale 1:50,000. IRS- IB False colour composites on scale 1:250,000 and IRS-IB Geo-coded data on scale 1:50,000.The physical elements like relief, slope and drainage are studied from SOI topographic sheets. The land degradation and ecologically disturbed pockets are demarcated from the study of IRS-IB Geo-coded data. The environmental impact assessment of the Nallamalai and Erramalai hilly regions are assessed using ecological disturbances and ecological degradation, wood smuggling, forest fires, soil erosion, mining, growth of mineral based industries and urbanization following [3] method and 


\section{International Journal of Science and Research (IJSR) \\ ISSN (Online): 2319-7064}

Index Copernicus Value (2013): 6.14 | Impact Factor (2014): 5.611

intensity of soil erosion [2] method, Sediment Yield Index and Erosion Index of the hills [6].

\section{Physiography and Environmental Degradation of the Nallamalai and Erramalai Hilly Region, Andhra Pradesh, India}

Physiographically the study area is divided into northern and northeastern Nallamalai hills, central Erramalai hills, eastern Velikonda hills, southeastern Palakonda hills and Tirumala hills, southwestern Seshachalam hills, western uplands and southern pediplain region. The altitude varies from 100 to 300 meters above MSL in uplands, pediplain region and Erramalai hills, 300 to 600 meters above MSL in Seshachalam, Palakonda, Velikonda, Tirumala and southern Nallamalai hills and above 600 to 900 meters above MSL in the northern Nallamalai hills and southeastern Tirumala hills. The major rivers drainage in Nallamalai and Erramalai hilly regions are Tungabhadra, Krishna and Pennar. The major tributaries are Hagari, Handri, Chtravathi, Papagni, Cheyyeru, Kunderu, and Sagiluru. Geologically the Nallamalai and Erramalai hilly regions are composed of Proterozoic formations consisting of Y.S.R.Kadapa and Kurnool series. They are formed of shales, quartzites, dolomites and limestone. The total reserved forest area of Nallamalai and Erramalai hilly regions is estimated to be $46,898.57 \mathrm{~km}^{2}$. Out of this about $1,919.52 \mathrm{~km}^{2}(4.09 \%)$ reserved forest is located in Anantapuram district. 15,312.30 $\mathrm{km}^{2}(32.64 \%)$ is found in Y.S.R.Kadapa district, $23,759.22 \mathrm{~km}^{2}(50.66 \%)$ is found in Kurnool district, $3.670 .90 \mathrm{~km}^{2}(7.83 \%)$ in Prakasham district and 2,236.63 km (4.78\%) in Mahaboob Nagar district in Telangana state. The type of forest is dry deciduous with scrubs. The tick forests are noticed in Nallamalai, Lankamallai, Palakonda, Velikonda and Tirumala hills.

The ecological degradation in the hilly terrain are taking place in the form of deforestation, construction of roads, new railway lines, power lines and major irrigation and hydroelectrical projects. Ecologically the northern part of Nallamalai hills are highly disturbed because of felling of teak plantations, back wood, bamboos and other fuel woods by local people and wood smugglers. The red sandalwood is being felled on a large scale in the Palakonda and Seshachalam hills. The development of good network of transportation in the Nallamalai hills has paved a way for smuggling of commercial wood. The hunting of animals in the Nallamalai hills by hunters is slowly reducing the population of animals. It is estimated that 10 to $15 \%$ of forest cover is lost due to illicit felling of trees by wood smugglers. In Nallamalai hills there are about 7,000 hectares of teak plantations, 62,000 hectares of black wood, 40,000 hectares of chinemani (Anogeisus Latifolia), 35,000 hectares of fuel wood and 1,18,000 hectares of Bamboos. On an average the Government of Andhra Pradesh is incurring a loss of 11/2 crores of rupees every year due to smuggling of wood. The wood is smuggled to Markapuram, Nandyla, Kurnool, Bhakrapet, Rajampet, Y.S.R.Kadapa, Badvel, Railway Kodur, Velgode, Allagadda, Narayanapuram, Ramavaram and Ahobilam. The places where the forest wealth is deteriorating are Vyyalawada, Diguvametta, Papineni palli,
Igukagundam, Akividu, J.P. Cheruveu, Gundlametu Project Sanjeevarayuni peta, malakonda peta, Nallaguntla, Pedda Dornla, Y.Cherlopalli, Chinna Manthanalla, Bodaswaralayam, Manigonda Palem, Tummalapalli, Bhakrapeta and Tallkonda. The forest wealth is lost due to forest fires during summer period.

The famous Lord Mallikrjuna and Goddess Bhramaramba Devi temple is located in Srisailam in the northern Nallamalai hills. The piligrims visit this temple regularly. The crowd of piligrims is very high during Mahasivarathri. The temple was constructed during satavhana period. In view of this famous temple the road transportation is well developed from Dornala to Srisailam and Srisailam to Achampeta. The rapid development in transportation in Nallamalai and Tirumala hills has paved a way for wood smuggling. The unscientific method of felling trees is leading to severe soil erosion. Ravine and gulley formations are very common in degraded forest pockets. On the other land on the southern sides of the Tirumala hills the world famous Lord Venteswara temple is located of about $25 \mathrm{~km}$ from Tirupathi at an altitude of about 1,000 meters above MSL. Lakhs of pilgrims visit this temple throughout the year. The popularity of their famous temple has also paved way for development of good roads in the Tirumala hills from Tirupathi to Tirumala.

\section{Mineral Resources and Land Degradation of Nallamalai and Erramallai Hills}

Unlike wood smuggling in Nallamalai, Erramalai hills are rich in mineral resources. The major minerals found are limestone, barytes, ochres, talc, clay, calcite, dolomite, steatite, copper, silica sand and iron ore. In Seshachalam hills the steatite, barytes, limestone, asbestos and clays are found. In Palakonda hills the major minerals are ochres, clays and barites. The Mangampeta barytes is located near Raily Kodur possess about 74 billions of high grade barytes. About 2,000 to 2,500 tons of barites are quarried daily. The limestone deposits are present in Yerraguntla, Tadipatri and Erramalai hills. About ten cement based industries are established and they are quarrying about 5,000 tones of limestone daily. The clay and napa slabs are quarried daily in and around Tadipatri, Ankireddi palli, Jammalamadugu and Bethamcherla. There are about 250 polishing units established in Bethamcherla, Dhone Ramapuram, Cherlopalli, Palkur, Gorlagutta, Racherla, Nereducherla, Tadipatri, Cherlopalli, Itikala, Chinatyala Palli, Ankireddipalli and Jammalamadugu. About 10,000 tonnes of clay and napa slabs are quarried daily.

The granites in the recent years are being exported to other countries. Black granites, pink granites and porphoritic granites are being exported from the villages of Beilakallu Rangapuram, Kapti and Krishnagiri. Lemon yellow and light green serpentine along with white dolomite and various shades of limestone are being used as chip stones. At present there are about 40 chipstone available at Valasala, Malkapuram Rangapuram, Kothapalli and Bethamcherla. "Calc Tujae a type of limestone useful in the manufacture of chemical, sugar and paper industries occur in Dhone, Banaganapalli, Koilakuntla, Nandikotkur and Nandyal Mandals. The resources of limestone in Erramalai hills are

\section{Volume 4 Issue 11, November 2015}




\section{International Journal of Science and Research (IJSR) \\ ISSN (Online): 2319-7064}

Index Copernicus Value (2013): 6.14 | Impact Factor (2014): 5.611

estimated to contain 3.7 million tones. A calcium carbide plant and Rayalaseema paper mill are established basing on the chemical grade limestone and bamboo plantation in Nallamalai hills respectively. Besides this, large resources of limestone are useful in cement industries. There are about ten cement plants creation in Tadipatri and Yerraguntla. Steatite is useful in soap industries. They are available at Muddavaram, Balapalapalli, Pendakal and Chandrapapalli of Dhone mandal of Kurnool District. Silica sand is found associated with Panyam Quartzites near Orvakal, Puricherla, Kalva and Kamarolu villages of Kurnool Mandal. It contains $99.62 \%$ of silica with less iron, which is suitable for glass industry. Quartz deposits are found in Gorantla and Haddapiri villages of Kodumur mandal and Kapirala village of Pathikonda mandal. The quartz is suitable for manufacture of silicon carbide, ferrosilicon, glass and sodium silicate. Superior quality yellow ochre useful for the manufacture of paints and other domestic uses occur mostly near and around Bethamcherla, Veldurthy and Ramalakota villages of Dhone mandal. At present yellow Ochre is utilised in ceramic tiles industry.

Barites found near Hussainapuram, Valasala, Chinnamalkapura, Balapalapalli and Ahobilam villages of Dhone and Allagadda mandals are useful in paint industry as a filter and in the manufacture of barium chemicals. In Cuddapah district the large mineral resources of barites and asbestos have helped to establish three major cement units, four asbestos based crushing and screening units, twenty barites based pulverizing units, fifty-eight slab cutting and polishing units and twenty others which include shales, chalk, crayon tiles, brick etc. these units are in Cuddapah district. In all, there are 115 mineral based units exist in Cuddapah district. The barites occur in Obulavari palli, Cuddapah, Pulivendla, Badvel and Rajampet mandals. In Managampet area of Obulavari palli mandal barites occur as bedded and massive type in the Pullampet formations of Cuddapah Super Group. About 102 mining leases are granted for the mining of barites in 2,865 acres. There are 14 mining leases covering an extent of 3,124.34 acres for mining of limestone in Cuddapah district which produces annually 2.3 million tones. There are 16 mining leases for exploitation of asbestos in an area of 2,056 acres. The annual production of the mineral is 2.3 million tones and the mineral occurs mainly in Brahmanapalle and Vempalle dolomites.

There are 8 mining leases granted in Anantapur district covering an area of 741.23 acres for barites. Steatite occurs in Seshachalam hills near Mustukota. The best variety (Lava grade) of steatite is being mined in and around Mustukota of Anantapur district. In total there are 132 units established for various mineral based industries like napa slab cutting and polishing units, cement products, abrasives, pulverizing units, stone ware pipes, jars, chalk crayons, granite cutting and polishing stone units, Magalore tiles and mosaic chips. Most of the slab cutting and cement units are situated near Tadipatri. From the study of mining areas it is found that the more mining areas are located between Buggana Palli and Dhone in Erramalai hills, between Tadipatri and Pulivendla in Seshachalam hills, between Yerraguntla and Cuddapah and barites mining in Mangampeta of Obulavari Palli mandal of Cuddapah district. The major mineral based industries are brick industry, burnt lime, barites, pulverizes, cement industries, calcium carbide, ceramic, slab cutting and polishing, granite stone cutting, manufacture of clay mosaic chips and tiles, lime klimes, napa slab polishing, stone cutting and polishing, steatitie based industry and talcum powder. They are located in Kurnool, in between Bugganna palli and Dhone, in between Gooty and Tadipatri, Anantapur, Pulivendla, Yerraguntla and Cuddapah.

Due to over exploitation of mineral resources in an unscientific manner ecologically the Erramalai and Seshachalam hills are very much disturbed leaving behind artificial pits, soil erosion and ecological degradation. The waste in quarrying of limestone, barites, asbestos, steatite, dolomite, napa slabs are dumped along the major road sides, mining sites in Ankiredddipalli, Managampet, Malkapuram, Dhone and Bethamcherla. In one of the sites of the Mangampet barites mining by the Andhra Pradesh Mineral Development Corporation, it is found that there is continuous inflow of water into the mine and the A.P. Mineral Development Corporation is incurring heavy expenditure to drain out the water from the mining site. Similarly such problems are noticed in mining of limestone, steatite, dolomite, calcite areas. The underground mining of steatite in Muttchkota and asbestos in Lingampalli are also generating the problem of underground water discharge. Unscientific underground mining in Mutchpeta and Lingampalli may lead to land subsidence. Detailed geophysical, hydrogeological and tectonic study has to be carried out in major mining sites to avoid land subsidence, underground water dischearge problem. In and around Dhone due to diffusion of brunt lime industry there is air pollution leading to many respiration diseases. Similarly in Yerraguntla the cement industries are also generating air pollution and dust pollution. In stone crushing, steatite based industry and talcum powder air, noise and dust pollution are noticed.

In Nallamalai and Erramalai hills and environs there are about eight class I towns, six class II towns, seventeen class III towns and eight class IV towns. About thirty-nine towns are noticed. In Nallamalai and Erramalai hills proper ten towns are noticed. The urbanization in this area is not very rapid. Only in industrial towns like Kurnool, Dhone, Tadipatri, Anantapur, Pulivendla, Markapur and Cuddapah the level of pollution is high. However detailed studies have to be carried out in each township to understand the nature and effects of pollution.

\section{Environmental Impact Assessment of the Nallamalai and Erramalai Hills :}

Based on location of mining area, degradation of forests, intensity of soil removal, Sediment Yield Index, Erosion Index, salinity, alkalinity, urbanization, industrialization, intensity of environmental pollution and ecological degradation the Environmental Impact Assessment Index has been evaluated adopting [3] method. From the Environmental Impact Assessment it is found that the E.I.A. Index is very high in the mandals covering Erramalai and Seshachalam hills. The E.I.A. Index is also high in the mandals where mining areas and mineral based industries are located. The E.I.A. is moderate in Nallamalai, Velikonda, Palakonda and Thirumala hills where ecological disturbances

\section{Volume 4 Issue 11, November 2015}




\section{International Journal of Science and Research (IJSR) \\ ISSN (Online): 2319-7064 \\ Index Copernicus Value (2013): 6.14 | Impact Factor (2014): 5.611}

are loss to moderates. The E.I.A. Index is low in irrigated areas, Kunderu valley, black soil plains, western mandals of Kurnool and Anantapur district. Further studies in depth at micro watershed level have to be carried out in the area where the E.I.A. Index is high and very high.

\section{Eco-Development Management of Erramalai Hills: \\ and Landscape the Nallamalai and}

For a long time natural forest has been exploited, cleared and suffered by man-made damage and has gradually declined in extent. It is estimated that in developing countries, forest are disappearing at a rate of $15-20$ million hectares per annum [5]. At present levels of demand the remaining tropical forest will disappear in 60 to 80 years [4]. In India the activities of man, on the whole, acted against the normal development and succession of forest vegetation.

The main causes of forest destruction are 1. Shifting cultivation, 2. exploitation for charcoal and fire wood, 3. intensive logging for veneer, saw timer and chip wood, 4. clearance for agriculture, 5. over grazing and gathering fodder for domestic animals, 6. forest fires, accidental or deliberate burning of forests, 7. urban and industrial expansion and 8 . ravages of war.

Pressures to exploit and clear forests have not stopped due to continuing demand for quality hard woods for veneers and saw timer. Best quality mahogany, teak, black wood, rose wood, red sandle wood and sapele come from old and mature trees in natural forests. Demand for all forest products is rising especially for pulp and paper. High rates of population increase will continue the pressure to settle on forestland because of good crops obtained for the first few years after clearance. In many tropical countries 90 per cent of all wood used is firewood for cooking and heating. Single trees, small woodlands and forest are all used for gathering firewood. Wood is not only burnt directly as firewood for house hold needs but much is gathered to make charcoal for both domestic and industrial use.

The forests of Nalamalai and Erramalai hills are degraded at a rate of $10 \%$ to $15 \%$ per annum by the tribal population and wood smugglers. The later are mainly responsible for rapid deterioration of forests. The loss of forest cover seems to be due to total negligence of duties of the forest officials, guards, watchers and beat gaurds. Therefore, the Government should impose stringent measures to control the smuggling of teak wood, black wood, high quality saw timber and red sandle wood in the Nallamalai, Erramalai, Palakonda, Thirumala, Velikonda and Seshachalam hills. Climatologically, the Nallamalai, Palakonda, Thirumala and Velikonda hills are favorable for forest growth due to good rainfall, humid and moist climate and water surplus. But, unfortunately the forests of these hills have become major income generation of wood smugglers. In places like Isuka Gunda, Bodeswaralaya, Uyyalavada, Diguvametta, Papinaenipalli, Akiveedu, J.P. Cheruvu, Gundlamotu project, Sanjeevarayunipeta, malakonda peta, Nallaguntla, Pedda Dornala, Y. Cherlopalli, Chinna Manthanala, Marrigonda, Palem, Tummalapalli, Velgode, Narayanapuram,
Ramavaram, Ahobhilam, Talakona and Bhakrapeta the forest resources are deteriorating at a faster rate. The Government of Andhra Pradesh has issued an order on August 28, 1992 to adopt the system of "Joint Forest Management" (JFM) to enable the local community to take part in foresting and benefiting by forest. The World Bank has given a soft loan of Rs.353.65 crores for the development of forests by identified schemes. Under Joint Forest Management scheme the loan was allotted to 1. Joint Forest Management stream (Rs.78.90 crores), 2. Joint Forest Management support (Rs.22.10 crores), 3. Production forestry (Rs.37.08 crores), 4. Social Forestry (Rs.35.69 crores), 5. Research (Rs.36.34 crores), 6. Bio-diversity conservation (Rs.27.68 crores), 8. Management Information System and Geographical Information System through satellite images (Rs.8.35 crores), 9. Forest Inventory (Rs.2.15 crores), 10. A.P. School of Forestry, Yellanadu (Rs.0.78 crores), 11. Collaborative Fodder Programme (Rs.1.72 crores), 12. Tribal Development Plan (Rs.25.73 crores) and 13. Andhra Forest Development Corporation (Rs.51.30 crores). About 105 Vana Samarakshana Samitis have been constituted through which local people are able to participate in the protection and fostering of the forests.

The Nallakalva Vana Rakshana Samithi in Atmakur mandal is turning out a good work. Some 22 Chenchu tribal families have left their previous abode at Rudrakoda and settled at Nallakalva in Atmakur mandal. The Chenchu tribals have been allotted 10 hectares in the reserve forest about $8 \mathrm{Km}$ away from Nallakalva in which they planted fruit bearing trees like guava, neredu and kunkudu. They tender these trees and have the right to share the sale proceeds from these trees. As it will be some years for yielding they are provided alternate employment. They have been assigned 18 hectares of patta land by the Revenue Department. The Chenchus ploughed the 18 hectares of land in June 1996 with a trench around the land to prevent animals like wild bores entering the land and spoiling the crop. The land was brought under Tribal development Plan as part of A.P. Forest Project. The 22 Chenchu families guard the forests from on slaughter forests by wood smugglers. Such Joint Forest Management schemes have to be implemented in other parts of Nallamalai, Erramalai, Palakonda and Thirumala hills besides careful water management and guarding of forests by forest officials. Under Nagarjuna Sagar Srisailam, wild life sanctuary extensive programmes of eco-development at village level are being carried out under the dynamic stewardship of Project Officer. During the field checks the researchers have visited the eco-development villages and found fruitful results have been noticed in protection of forests and wild life. Such eco-friendly villages have to be encouraged in remote areas of the hills with the local Chenchu tribal people for protection of natural forests. Forest plantation projects have to be taken in degraded forest areas to meet the growing demand of fuel wood and saw wood. The National forest Policy of India has also laid down certain basic principles for proper management and conservation of the forest resources of the country such as 1 . Classification of forests according to functional aspects into protected forests, reserved forests and village forests. 2. Expansion of forest cover by planting trees in order to ameliorate the physical and climatic conditions for the welfare of the people, 3. provision for ensuring progressive increasing supplies of fodder for animals and timber for agricultural 


\section{International Journal of Science and Research (IJSR) \\ ISSN (Online): 2319-7064 \\ Index Copernicus Value (2013): 6.14 | Impact Factor (2014): 5.611}

implements and firewood to local inhabitants nearer to the forests. 4. opposition of rock less extension of agricultural land at the cost of forest land and 5. extension of forested area by massive plan of tree plantation on a large scale at war-footing so as to bring 33 per cent of country ${ }^{\text {es }}$ area under forest cover. Though there are strict guidelines from the Government of India that forests should not be diverted to non-forestry uses and in case, if the diversion of forested area to other forms of land uses is necessary and unavoidable (such as construction of dams and reservoirs, installation of industrial plants, construction of road, railway lines and houses). It should be done with the approval and concurrence of the State Government and the loss of forests due to their diversion to other proportionate areas. But this guideline is seldom followed. Recently, the Government has banned the cutting of green trees by the public without having prior permission from the Government. It appeared that directive principles and laws cannot guarantee safeguard of forests from their destruction and therefore, Government implemented the Joint Forest Management for the safe guard of forests. If this scheme is successfully implemented the dwindling of forest resources could be reduced to a large extent and safeguard the natural ecosystem.

The unscientific and unauthorized mining activities are taking place in Erramalai and Seshachalam hills. The mining of dolomite, limestone, yellow ochre, steatite, calcite, clay, napa slabs, barites and asbestos in these hills are degrading the land at a faster rate, leaving behind artificial pits. The unscientific underground mining of steatite in Mutchukota and asbestos in Lingampalli may lead to land subsidence. Slumping is very commonly noticed in mining of dolomite, calcite and ochre from the debris slopes of hills. The belt between Bungganapalli and Dhone is very much disturbed for mining activities. Illegal mining has to be curbed totally by the A.P. State Mining and Mineral Development Corporation is incurring heavy expenditure to drain out the underground water from the mining pits. Similarly, the mining of napa slabs in and around Ankireddi palli, Tadipatri, Jammalamadugu and Bethamcherla has also left deep artificial pits and paved a way for dumping waste. The waste is being dumped along the roadsides and in and around mining areas. Large scale mapping on 1: 25,000 a detailed study of hydro-geological conditions, effects of land degradation and Environmental Impact Assessment has to be carried out for each mining area in the Erramalai and Seshachalam hills to bring out environmental implications and to suggest appropriate measures to minimize land degradation.

Due to availability of rich mineral resources in Erramalai and Seshachalam hills a number of mineral based industries have been developed in between Bugganapalli and Dhone, Jammalamadugu and Cuddapah, Gooty and Tadipatri, around Anantapur and Pulivendla. No doubt rapid rate of industrial development has given economic prosperity to human society, new dimension to socio-economic structure and provided material comforts but has also created manifold environmental problems. A detailed study on various problems of environment has to be carried out in each site of industrial units. It has been found due to burn lime industries diffused in a valley near Dhone has generated air pollution leading to respiratory infections. The effects of air pollution are also high in Yerraguntla due to development of cement industries. The diffusion of napa slab cutting and polishing industries in Tadipatri and Bethamcherla have generated noise pollution and stone crushing and pulversing industries have created dust pollution. Large scale mapping of available mineral resources, industries, effects of land degradation and environmental problems have to be carried out for various mineral based industries and appropriate measures and suggestions have to be formulated to curb the ill effects of environmental pollution.

Increasing concentration of population in urban centers and origin and expansion of new urban centers due to industrial expansion and development are responsible for rapid rate of exploitation of mineral resources and several types of environmental degradation and pollution. However, in Nallamalai and Erramalai hills the Urbanization process is very slow and it is picking up due to development of mineral based industries and increased mining areas. The positive and negative effects of urbanization have to be studied for each township developed in the Nallamalai and Erramalai hills.

Environmental management involves judicious and gainful utilization of natural resources for socio-economic development, maintenance of environmental quality by persuing ecological principles, separation of degraded land and environment, to control environmental degradation and pollution, to reduce the impacts of extreme events and natural disasters, to make optimum utilization of natural resources by recycling and sensing waste material produced, to assess the impacts of proposed projects and activities on environment, to review and revise the existing technologies of production in terms of their adverse effects on the environment and to formulate laws and regulations for the implementation of environmental protection and conservation programmes to maintain environmental quality. The components of environmental management includes five basic aspects namely environmental perception and public awareness, environmental education and training, management of resources, Environmental Impact Assessment and control of environmental degradation and pollution. The strategies of environmental management may be formulated through spatial and methodological considerations. Environmental management may be approached local, regional, state, national or international levels and the management strategies may be chalked out on the basis of needs, aspirations, perceptions, priorities and inhibitions of the individuals, society and Government. The conservationist approach to environmental management is to restrict and minimize the adverse effects of human activities during utilization of natural resources on environment and to optimize the productivity of natural environmental ecosystem by adopting environmentally safe technologies. The fundamental ecological issues to be considered for environmental management include components, dynamics of biospheric ecosystems, form, function and equilibrium of ecosystems, ecological changes through time and space, exploitation and utilization of ecological resources and impact of human activities on environment leading to environmental degradation and pollution. In continuation, studies could be carried out village levels to map the areas effected due to land degradation, their ill effects and suggest

\section{Volume 4 Issue 11, November 2015}




\section{International Journal of Science and Research (IJSR) \\ ISSN (Online): 2319-7064}

Index Copernicus Value (2013): 6.14 | Impact Factor (2014): 5.611

appropriate measures for optimum utilization, conservation and eco-development of villages in Nallamalai and Erramalai hills.

\section{Conclusion}

The ecologically degraded zones are mapped from IRS IB Geo-coded data on scale 1:50,000. It is found that the Erramalai hills are subjected to rapid erosions metal degradation due to over exploitation of mineral resources. The degradation in the Nallamalai hills is due to illicit deforestation.

\section{References}

[1] V.V. Dhrva Narayan, G. Sastry, Rambabu, "Conservation in a quarter of the catchment reduces sediment production by half," Indian Journal of Soil conservation. 9 (2\&3), 1985.

[2] E.M. Flxman, " Soil Conservation Service, Technical Service Centre Advisory Enf. Po-1 Sediment Yield Predictive Equation," 1971.

[3] C.L. Jenkins, "Environmental considerations in Tourism Development," Indian Journal of Tourism and Management, Vol.1. No.2, pp. 143-163, 1992.

[4] T.S. Spears, " Can wet Tropical Forests Survive Common wealth Forest Review 58," pp 165-180, 1979.

[5] World Bank, " Forestry," Sector Policy Paper World Bank, Washington, 1978.

[6] D. Zacher, " Soil erosion," Elsevier Scientific Publishing Company, New York, 1982.

\section{Author Profile}

Prof. M. Sambasiva Rao, Dept. of Geography, Sri Krishnadevaraya University, Anantapuramu, Andhra Pradesh 515003.

Dr. K. Somanna, Post Doctoral Fellow, Dept. of Geography, Sri Krishnadevaraya University, Anantapuramu, Andhra Pradesh 515003.

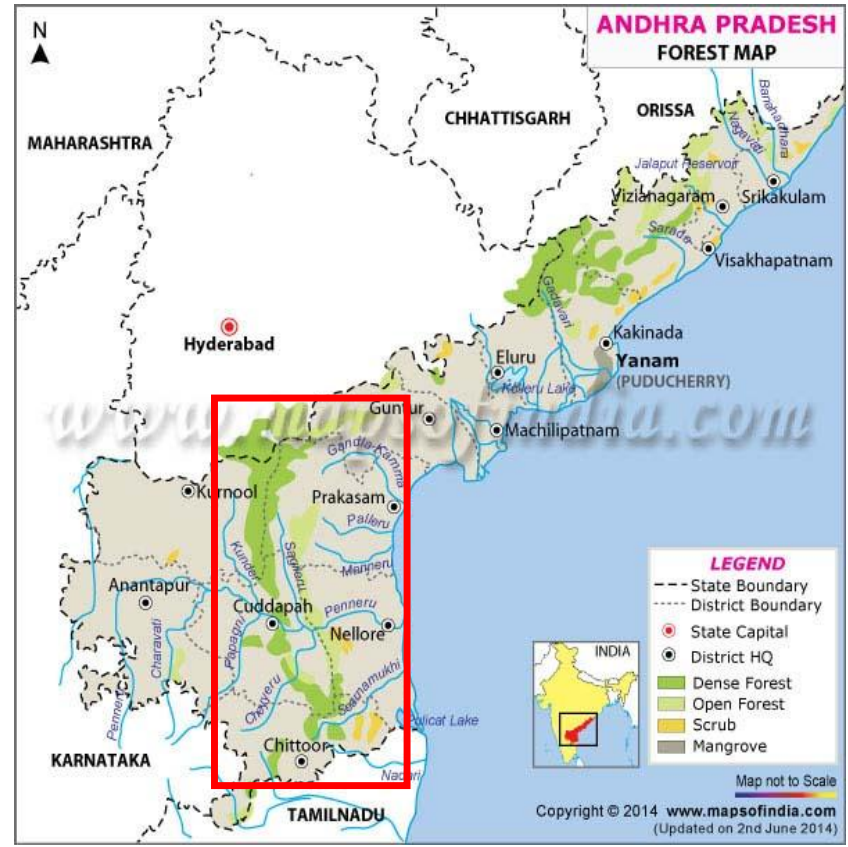

